Archived version from NCDOCKS Institutional Repository http://libres.uncg.edu/ir/asu/

\title{
Appalachľan
}

B O O N E, N O R T H C A R O L I N A

\section{Questioning The Prevailing Narrative About Elementary Science Teachers: An Analysis Of The Experiences Of Science Teacher Enthusiasts}

\author{
By: Leslie U. Bradbury and Rachel E. Wilson
}

\begin{abstract}
The purpose of this study is to challenge the prevailing negative narrative related to elementary science teaching by investigating the experiences of elementary teachers who identify as science teacher enthusiasts (STEs). Holland, Lachiotte, Skinner, and Cain (1998)'s conception of identity as an ongoing production or construction in a sociocultural context served as a theoretical framing for exploring structural and personal supports and constraints related to the development of elementary teachers' science teaching identities. Through interviews with 13 inservice elementary teachers with a range of experience (1-40 years), we found that students' enthusiasm for science, connections with other enthusiasts, and opportunities for integrating science with other content areas were the major supports for consistent science teaching. Positive emotions associated with these supports helped the participants mitigate constraints such as lack of time, resources, testing, and not feeling comfortable with the science content frequently associated with portraits of elementary teachers. By understanding the experiences of STEs, science educators can use their role as preservice educators and professional developers to provide these supports to bolster the science teaching identity trajectories of individuals with whom they work.
\end{abstract}

Bradbury, LU, Wilson, RE. Questioning the prevailing narrative about elementary science teachers: An analysis of the experiences of science teacher enthusiasts. Science Education. 2020; 104: 421- 445. https:// doi.org/10.1002/sce.21574. Publisher version of record available at: https://onlinelibrary.wiley.com/doi/ full/10.1002/sce.21574 


\title{
Questioning the prevailing narrative about elementary science teachers: An analysis of the experiences of science teacher enthusiasts
}

\author{
Leslie U. Bradbury (i) | Rachel E. Wilson
}

Department of Curriculum and Instruction, Appalachian State University, Boone,

North Carolina

\section{Correspondence}

Leslie U. Bradbury, Department of Curriculum and Instruction, Appalachian State University, ASU Box 32047, Boone, NC 28608.

Email: upsonlk@appstate.edu

\begin{abstract}
The purpose of this study is to challenge the prevailing negative narrative related to elementary science teaching by investigating the experiences of elementary teachers who identify as science teacher enthusiasts (STEs). Holland, Lachiotte, Skinner, and Cain (1998)'s conception of identity as an ongoing production or construction in a socio-cultural context served as a theoretical framing for exploring structural and personal supports and constraints related to the development of elementary teachers' science teaching identities. Through interviews with 13 inservice elementary teachers with a range of experience (1-40 years), we found that students' enthusiasm for science, connections with other enthusiasts, and opportunities for integrating science with other content areas were the major supports for consistent science teaching. Positive emotions associated with these supports helped the participants mitigate constraints such as lack of time, resources, testing, and not feeling comfortable with the science content frequently associated with portraits of elementary teachers. By understanding the experiences of STEs, science educators can use their role as preservice educators and professional developers to provide these supports to bolster the
\end{abstract}


science teaching identity trajectories of individuals with whom they work.

\section{KEYWORDS}

elementary science teachers, emotion, enthusiasm, identity, inservice teachers

Research articles and book chapters related to elementary science education frequently include a section in the literature review lamenting the state of elementary science teaching (e.g., Davis, Petish, \& Smithey, 2006; Roth, 2014). Often cited in these literature reviews are reports from the Horizon Group which has completed a regular survey of the state of science and mathematics education across the US since 1977 (e.g., Weiss, Pasley, Smith, Banilower, \& Heck, 2003). Findings in the most recent survey indicate that elementary teachers feel less prepared to teach science and spend considerably less time teaching it daily as compared to reading/language arts and mathematics. For example, in K-3 classrooms when teachers report the amount of time spent daily on each subject, they report spending $86 \mathrm{~min}$ per day on reading, $59 \mathrm{~min}$ on math, and $21 \mathrm{~min}$ on science (Banilower et al., 2018). These results are strikingly similar to the 1977 report which indicated that an average of 19 min per day was spent on science in $\mathrm{K}-3$, and that only $22 \%$ of elementary teachers felt very well qualified to teach science, whereas 63\% felt well-qualified to teach reading (Weiss, 1978).

The findings of these articles and reports, along with conversations that we have engaged in with other science educators, have led us to consider the prevailing narrative related to elementary science teaching as a deficit view of elementary science teaching. Frequently discussed topics in this narrative include elementary teachers' lack of self-efficacy and enthusiasm for science teaching, as well as their lack of preparation and content knowledge (Appleton, 2003; Davis et al., 2006). However, during the previous 5 years, we have spent a great deal of time working with elementary teachers in our local schools on a variety of projects that have led us to a different view of elementary teachers and their attitudes toward science teaching. These initiatives have included planning and teaching lessons with teachers in their classrooms, placing preservice students in internships in local classrooms, and implementing professional development workshops where elementary teachers were the participants. These experiences have put us in contact with a group of elementary teachers that we have labeled science teacher enthusiasts (STEs). These STEs enjoy teaching science, seek out opportunities to improve their science teaching, and often take on leadership roles in their schools related to science teaching. Our goal in this project is to offer their voices as a counter-narrative to the prevalent pessimism about elementary science teaching.

While we do not assert that enthusiasm for science is the dominant view amongst elementary teachers, we do feel that it is important to share the voices of elementary STEs because they have developed a professional identity that differs from that often reported (Appleton, 2003; Roth, 2014). Though previous research has been important in illuminating a number of issues including elementary teachers' lack of content preparation and self-efficacy for science teaching, so far that research has not lead to significant changes in the amount of time spent teaching science or elementary teachers' feelings of competence and preparedness as evidenced by continuing reports (Banilower et al., 2018). Our hope is that by presenting a counter-narrative about elementary science teaching and teachers, we might open a new conversation. We want to think deeply about the potential to learn with and from these STEs so that we as science educators can rethink how we are educating our preservice teachers, and how we might be agents of change and a part of a collaborative team to improve elementary science teaching in our local schools.

In pursuit of this goal of reframing narratives, we thought it best to begin by learning about the perspectives of STEs in our local area. Therefore, the research questions guiding this study are: What factors do elementary STES 
perceive as influential to their teaching identity? What role do emotions play in how elementary teachers develop a positive science teaching identity?

\section{1 | LITERATURE REVIEW}

\subsection{Constraints on elementary science teaching}

Even for those elementary teachers who want to include science as a regular component in their teaching, there are constraints that make that goal difficult for them to achieve. Some of the constraints are structural in nature, while others are related to the individual. Examples of structural constraints include lack of administrative support for science teaching often related to the emphasis on standardized testing (Milner, Sondergeld, Demir, Johnson, \& Czerniak, 2012; Upadhyay, 2009); access to materials and resources (Carrier, Whitehead, Walkowiak, Luginbuhl, \& Thomson, 2017; Murphy, Neil, \& Beggs, 2007), and time to prepare for science teaching (Davis et al., 2006; Goodrum, Cousins, \& Kinnear, 1992).

Elementary teachers may feel pressure to minimize the emphasis on science teaching from administrators or other teachers in their context. This pressure is felt by inservice elementary teachers (e.g., Carlone, Haun-Frank, \& Kimmel, 2010) and is a concern facing novices about to enter the profession (Pedretti, Bencze, Hewitt, Romkey, \& Jivraj, 2008). Using survey data from in-service elementary teachers, Milner et al. (2012) reported that some teachers had been told directly by administrators not to teach science so that there was more time to focus on language arts and math. In a study of "tempered radicals" (elementary teachers who viewed science teaching as part of their identities but felt like outsiders in their school context), participants reported feeling pressure to have their students perform at high levels on reading and math tests with the effect that science was marginalized (Carlone et al., 2010). In another instance, innovative teaching practices that the classroom teacher wanted to implement for science teaching were not approved of by the administration or other teachers at the school (Zembylas, 2004). Preservice teachers worry that their desire to teach science would cause them to be "outside of the community" (Pedretti et al., 2008, p. 950), because their prevailing belief is that science is not a valued part of the curriculum in many elementary schools.

Lack of access to resources and materials for teaching science is a concern that is frequently mentioned in the literature related to elementary science teaching (Milner et al., 2012; Murphy et al., 2007). This difficulty in securing resources can be perceived by novice elementary teachers as an indication of the priority that administrators place on science teaching (Appleton \& Kindt, 2002; Carrier et al., 2017). In addition to the lack of resources for teaching science, elementary teachers may also face difficulty in finding curriculum materials and lesson ideas that are appropriate (Davis \& Smithey, 2009).

Time to prepare for science lessons is another factor that can hinder elementary teachers' ability to teach science. Issues related to time management may be especially pronounced for novice teachers who struggle to plan science lessons as well as to acquire the materials that they need to enact a science lesson (Davis et al., 2006). However, time can be a constraint for more experienced teachers as well. In a study of 20 teachers including second-, fifth-, and sixth-grade teachers, Goodrum et al. (1992) reported that elementary teachers found the amount of time required to prepare and organize materials was problematic, and when there were time constraints, science was the first content area that they dropped from instruction. These responses were similar to participants in Milner et al. (2012), study who reported difficulty finding time to plan for science lessons.

The above documented deficit-oriented view of elementary science teaching paints a bleak picture. Therefore, our purpose is to provide a different perspective about elementary science teaching grounded in the experiences of individual teachers with a positive science teaching identity. 


\section{2 | Supports for elementary science teaching}

Though elementary teachers face constraints in their efforts to include science as a regular part of the curriculum, there is evidence that factors are present to support them as they persevere to incorporate it; the most prevalent of these supports is the enthusiasm that elementary students feel for science (Goodrum et al., 1992). Hargreaves (1998) reported that as teachers prepare lessons, they consider criteria such as whether the lessons will be exciting and engaging for students. While Hargreaves' study was not specific to science, a similar dynamic is present for elementary teachers as they plan science lessons. In an investigation of 13 elementary teachers who enacted reform-based elementary science pedagogy, participants reported that students' enthusiasm for science was one of the forces driving their willingness to challenge prevailing norms and include science in their teaching (Carlone et al., 2010). Similarly, the elementary teacher studied by Zembylas (2004) explained that she was willing to challenge the pushback that she faced from other teachers at her school because the students had such a positive reaction to her science lessons. Carrier et al. (2017) described a comparable pattern for preservice teachers who used the enthusiasm of the students to strengthen their views of themselves as elementary science teachers.

Because time to teach science is such a constraint at the elementary level, one way that teachers have navigated this issue is by integrating science with other content areas (Bradbury, 2014). There are examples in the literature of elementary teachers using science as a vehicle to make math, reading, and writing relevant to the students (Carlone et al., 2010). Researchers point to the benefits of having students combine experiences with hands-on, inquiry-based activities and language arts-based supports such as reading informational texts that relate to the direct experiences to promote student understanding of the science content (Romance \& Vitale, 2001; Varelas, Pieper, Arsenault, Pappas, \& Keblawe-Shamah, 2014). The integration of science and language arts can improve students' knowledge of the science content as well as their performance on measures of language arts achievement making integration a feasible approach for increasing the amount of time for science instruction at the elementary level (Girod \& Twyman, 2009; Romance \& Vitale, 2012). In addition to the academic benefits of integration, this approach has been shown to boost students' enthusiasm for science (Patrick, Mantzicopoulos, \& Samarapungavan, 2009; Shymansky, Yore, \& Anderson, 2004).

Researchers have also noted the importance of teachers' professional relationships as a support for their work (i.e., Feille, Nettles, \& Weinburgh, 2018; Hargreaves, 2001). Teacher relationships "stimulate and energize professional engagement" (Hargreaves, 2001, p. 517). In writing about teachers, Hargreaves (1998) emphasizes teachers' excitement when they develop ideas with colleagues. Similarly, Jones and Leagon (2014) noted that when science teachers worked together in a professional learning community and experienced success, it built their selfefficacy for teaching science. Appleton and Kindt (2002) described how the support of other teachers encouraged newcomers to try science teaching ideas they would have been hesitant to attempt on their own. Hargreaves (2001) explains that teachers enjoy working in professional communities amongst other like-minded individuals. When Carlone et al's. (2010) participants were not able to find support amongst their colleagues in their school, they sought opportunities outside of school to get knowledge and support for their science teaching, for example, seeking science professional development.

\section{3 | Teacher identity}

While constraints and supports are important considerations in whether and how elementary teachers choose to incorporate science in their curriculum, teacher identity is another important factor (Carlone et al., 2010). While the word identity is frequently used in research on classroom teachers, there is no one agreed upon definition. Helms (1998) provides an explanation which states that "professional context, actions, how others see us, and moral sensibilities each play a role in defining a sense of self" (p. 814). Beauchamp and Thomas (2009) emphasize the actions that result from identity explaining that identity provides teachers with a framework for "how to be, 
how to act, and how to understand their work and place in society" (p. 178). Multiple authors have contributed to the discussion of the components that comprise teacher identity. One essential component is a sense of self (Avraamidou, 2014) which helps to determine the approach that teachers use in their instruction (Beijaard, Meijer, \& Verloop, 2004; Coldron \& Smith, 1999). Teachers' ways of interacting with colleagues and students (Avraamidou, 2014; Luehmann, 2007), as well as the expectations that others hold for teachers (Beijaard et al., 2004), are components of teacher identity.

One characteristic of teacher identity frequently reported in the literature is that it is not a fixed entity, but rather changes over time (Avraamidou, 2014). Danielsson and Warwick (2014, p. 107) refer to teacher identity as a "constant becoming" while Gee (2000) asserts that it can be unstable. Beijaard et al. (2004) point out that identity is not "something one has," rather identity development is an ongoing process. As teacher identity morphs over time, the context in which the teacher works plays an important role in determining the trajectory of identity development (Beijaard et al., 2004) because teacher identity is socially constructed (Avraamidou, 2014; Coldron \& Smith, 1999). In four separate studies that were specific to science teacher identity, researchers documented the changing nature of the participants' science teacher identities as they gained experience with positive science teaching episodes (Carlone et al., 2010; Carrier et al., 2017; Helms, 1998; Jones \& Leagon, 2014). Therefore, one factor that science education should research related to developing positive science teacher identities is the role that emotions play in how teachers make sense of their experiences.

\section{4 | Teacher emotions}

Teaching has been described as an emotional practice with teachers feeling passionately about their students and the moral calling of their profession (Hargreaves, 1998; Nias, 1996). We are using the definition described by Rivera Maulucci (2012): "emotions are experienced over time and include cognitions, bodily responses, and actions" (p. 124). Successful teaching is built on the idea of developing close relationships with other people, including students and other colleagues, and emotions are an important component of those relationships (Hargreaves, 2001). Because teachers' emotions are experiences that occur within their relationships with other people in specific contexts with particular norms, they are seen as socially constructed (Kelchtermans, 2005; Rivera Maulucci, 2013; Zembylas, 2004). Another important characteristic of teachers' emotions is that they are not separate from teachers' thinking, but rather an integral part of their sense-making (Rivera Maulucci, 2013).

The work of Taxer and Frenzel (2015) explores the idea that teachers both express and conceal their positive and negative emotions in socially acceptable ways that enable them to present themselves as professionals. Teachers express positive emotions such as happiness, pride, and enthusiasm more frequently than they do negative emotions like disappointment and anger (Taxer \& Frenzel, 2015). The most frequently displayed positive emotion for teachers is enjoyment (Frenzel, 2014). In a study of seventh and eighth-grade math teaching, demonstrated teacher enthusiasm was positively linked to both student and teacher enjoyment (Frenzel, Goetz, Lüdtke, Pekrun, \& Sutton, 2009). Teachers' enthusiasm had a positive impact on the students' motivation to learn the content (Frenzel et al., 2009). Conversely, students' engagement with teachers was reported as an important factor in supporting the construction of positive relationships between teachers and students (Hagenauer, Hascher, \& Volet, 2015). There are also positive associations between teachers' enthusiasm and their self-efficacy for teaching (Kunter, Frenzel, Nagy, Baumert, \& Pekrun, 2011; Taxer \& Frenzel, 2015).

While teachers express positive emotions more frequently than negative ones, negative emotions are present in teachers' work (Taxer \& Frenzel, 2015). There is not a consensus on which negative emotion is expressed most frequently. In a literature review about teacher emotions, Frenzel (2014) reports that anger, which can be directed at oneself or towards others, is the most prominent negative emotion. However, in a study of 266 secondary teachers, Taxer and Frenzel (2015) found that disappointment was the most frequently displayed negative emotion. Though there is continued discussion about which emotions teachers feel comfortable displaying, there is an 
agreement that emotions play an important role in teachers' sense making about their work and can influence their teaching identities.

\section{5 | Epistemic affect in science}

The second area of relevant emotions-related research is investigating the role of epistemic affect on motivation for learning or engaging in the work of science (Jaber \& Hammer, 2016a; 2016b). Epistemic affect refers "to feelings and drives connected to epistemic experience and objectives in the doing of science" (Jaber \& Hammer, 2016a, p. 161). Jaber and Hammer (2016b) posit that there are five themes of affect related to scientists' practices that are relevant for research connected to science education. These five themes are: "the pleasure in studying phenomena, the feelings involved in scholarly interactions, empathy with the object of study, affective signals of cognition, and meta-affect" (p. 192). When considering elementary students engaging in science practices, the themes of the pleasure of studying phenomena and affective signals of cognition are particularly applicable to teachers' experiences of facilitating inquiry-based science lessons. Jaber and Hammer (2016b) describe the pleasure of studying phenomena as encompassing "joy in discovery" and enjoyment within doing science" (p. 192). The theme of affective signals of cognition includes feelings such as excitement or restlessness related to developing questions and ideas in an investigation (Jaber \& Hammer, 2016b). These emotions are likely to be apparent to teachers in a science lesson because they would have outward displays, such as facial expressions, student comments, and gestures. Epistemic affect, therefore, is an emotional component of science learning for students (Jaber \& Hammer, 2016a; 2016b), and potentially influences their teachers' emotional experiences in the classroom.

\section{2 | THEORETICAL FRAMEWORK}

The theoretical grounding of this study is based on a practice theory of identity described by Holland, Lachiotte, Skinner, and Cain (1998). This perspective on identity highlights the link between individual identity development and context (Holland et al., 1998). These authors argue that people continually author their identities as they respond to situations in context. Identities, therefore, are being consistently (re)formed or (re)produced based on experiences in the socio-cultural and historical contexts within which they live and work because of how they respond and make meaning of those experiences. Identities are constructed over time in the "day-to-day and on-the-ground relations of power, deference, and entitlement, social affiliation and distance-with the socialinteractional, social-relational structures of the lived world" (Holland et al., 1998, p. 127). Therefore, identity is neither completely an individual construction nor is it simply constructed in social milieus. It is a dialectical process between self and others in context and is constructed through the practices that people engage in as a response to their positioning.

The contexts, or lived worlds, within which a person authors their identity is described by Holland et al. (1998) as a figured world, a "socially and culturally constructed realm of interpretation in which particular characters and actors are recognized, significance is assigned to certain acts, and particular outcomes are valued over others" (p. 52). An example of a figured world relevant to this study would be public elementary schools in a particular state or district, as such schools would share similar institutional structures and influences that shape the positioning of elementary teachers and what their job entails. In our thinking, the figured world of a public elementary school is the lived world in which these teachers are practicing and constructing their identities as STEs.

Elementary teachers develop their identity in the figured world of the elementary school as they make meaning of their experiences. In the negotiation of sense making of experiences between self and others in context, the whole person is involved, with emotions playing a large part in how people act in a given situation. Holland et al. (1998) describe an individual's identity in response to context as "a set of dispositions towards themselves in 
relation to where they can enter, what they can say, what emotions they can have, and what they can do in a given situation" (p. 143). Emotions play a role in how teachers make sense of their experiences, interpret their position in a given situation, as well as how they perceive themselves in relation to their work. Additionally, emotions can be the impetus for how a person responds to a particular event based on how they feel positioned in that figured world. Identity work, therefore, happens as a result of actions taken by a person in their day-to-day work based on how they feel about a particular situation.

In responding to a given situation, a person will consider their emotions as well as what they feel they have the power to do. Someone who is trying to author an identity that differs from the way they are being positioned may look for a way to improvise, which requires the use of mediating tools or devices. The mediating tool or device is developed by "assigning meaning to an object or behavior" and is always developed within a "locus of social activity, a place in the social world" (Holland et al., 1998, p. 36). Mediating tools are a way for a person to modify something about their situation to exert agency in their world. The development and use of mediating tools, therefore, is a means for people to respond differently to their positioning, but Holland et al. (1998) emphasize that the process "involves effort, may not succeed, and, except for rather small-scale changes, is clearly beyond the ability of any individual to accomplish alone" (p. 40). So a teacher may wish to make a change in the figured world of their school, but the effort cannot be accomplished individually, as the work they are involved in is subject to influences at the school, district, state, and national levels. Therefore, the work of authoring an identity that pushes back against positioning requires effort, and continued dialogue with the figured world.

\subsection{Teacher identity and emotions}

While identity and emotions are two distinct constructs in the science education literature and research on teachers more broadly, there are connections between these two ideas. Several researchers view emotions as one component of a teacher's identity (Avraamidou, 2014; Hargreaves, 1998, 2001). Others point to the reciprocal relationship between identity and emotion, emphasizing the idea that emotions can play a role in shaping a teacher's identity; and likewise, a teacher's identity impacts the individual's emotions (Rivera Maulucci, 2012; Schutz, Cross, Hong, \& Osbon, 2007).

Both identity and emotions are shaped by the professional experiences that teachers have throughout their careers (Nias, 1996). Researchers posit that emotions are one of the factors that influence a teacher's changing identity (Beauchamp \& Thomas, 2009; Geijsel \& Meijers, 2005).

Just as the context in which a teacher works impacts the development of identity (Beijaard et al., 2004), so to it shapes teachers' emotions and how they are displayed (Kelchtermans, 2005; Nias, 1996; Rivera Maulucci, 2013). Discussions of teacher emotions can bring to light the ways that teachers are making sense of their identities in their context (Kelchtermans, 2005; Rivera Maulucci, 2013).

\subsection{Gaps in the literature that we are filling}

While there are several studies that investigate preservice and novice teachers and their identity development for science teaching (e.g., Avraamidou \& Zembal-Saul, 2010; Carrier et al., 2017), there are few that explore the identity development of more experienced elementary teachers with respect to science teaching (Avraamidou, 2014). Two decades ago, Helms (1998) pointed out the dearth of studies examining the role of subject matter in teacher identity development and little has changed in that time. Additionally, as novices and experienced teachers position themselves and develop their identities within particular contexts, emotions play an essential role (RiveraMaulucci, 2013). Currently, the majority of literature related to emotions in schools centers on student emotions rather than teacher emotions (Petersen \& Dohn, 2017). There is an emerging body of research focused on 
measuring teacher emotions during the act of teaching (e.g., Tobin, King, Henderson, Bellocchi, \& Ritchie, 2016), but the findings may be hindered by the emotions that teachers feel comfortable displaying. The focus for much of the literature related to teachers' emotions focuses on burnout, rather than identity (Frenzel, 2014). By illuminating factors that contribute to science teacher identity development for elementary teachers (Avraamidou, 2014) and the role that emotions play in that identity development (Rivera-Maulucci, 2013), science educators are better positioned to develop and implement preservice programs that better prepare novices to develop a strong science teaching identity. In addition, such research can be used in planning professional development programs to support inservice teachers in developing a positive science teaching identity.

The purpose of our study is to learn more about the identities of elementary STEs and how their experiences have shaped their teaching of science. As enthusiasts for science, these teachers have an identity that differs from that of the commonly described elementary teacher in the literature. We wanted to explore the factors that these elementary STEs perceive as being influential in their authoring of a positive science teaching identity as a way to understand their figured world and how to support them and other teachers in their work to continually practice the teaching of science.

\section{3 | METHODOLOGY}

Qualitative research design is appropriate for questions of an exploratory nature in which the researcher seeks to understand a phenomenon in detail and in-depth (Creswell, 2007). Furthermore, when a researcher wants to highlight the perspective of participants, qualitative inquiry allows for engagement with participants' own words and ideas (Patton, 2002). Because of our interest in the experiences of elementary STEs, a rarely discussed group in the research literature, a study using grounded theory methods (Charmaz, 2014) allowed us to bring forward and highlight the experiences of professionals who do not fit the prevailing narrative of elementary teachers who are uncomfortable, dislike, and/or spend little time teaching science.

\section{1 | Participants}

Our 13 participants have a wide range of expertise as elementary teachers with one to 40 years of classroom experience. Table 1 shows the demographic information for each of the participants. In terms of sex and race/ ethnicity, our participants are representative of the majority demographic of elementary teachers in our particular region of the southeastern United States, but also when compared to elementary teachers nationwide (i.e., White females; Snyder, de Brey, \& Dillow, 2018). However, all but one of these science enthusiasts worked in Title 1 schools, and all but one in a rural setting.

We used a snowball sampling method to select participants in the study. Initial participants were chosen based on the following criteria: (a) elementary teachers or teacher candidates; and (b) interest in teaching science regularly in their classroom. Many of these were individuals who we have worked within their classrooms because of their interest in science teaching. When we asked for and received consent from each of the participants, we were not in a position of authority over any of the teachers. At the end of each interview, we asked the participants to recommend other STEs that they knew in their school and district with whom they thought we should speak. We then contacted these elementary teachers and invited them to participate.

\section{2 | Data collection}

Because we were interested in the personal experiences and perspectives of elementary STEs, we chose interviews as our primary data source (Patton, 2002). We interviewed each participant, with interviews ranging from 30 to 
TABLE 1 Participant information

\begin{tabular}{|c|c|c|c|c|c|}
\hline $\begin{array}{l}\text { Participant } \\
\text { pseudonym }\end{array}$ & Sex & $\begin{array}{l}\text { Race/ } \\
\text { ethnicity }\end{array}$ & $\begin{array}{l}\text { Years of teaching } \\
\text { experience }\end{array}$ & $\begin{array}{l}\text { Current grade } \\
\text { level }\end{array}$ & $\begin{array}{l}\text { Time spent teaching science per } \\
\text { week (days/week, minutes) }\end{array}$ \\
\hline Jenna & $\mathrm{F}$ & White & 12 & 1 & 5 days/week, $20-60 \mathrm{~min}$ \\
\hline Kelly & $\mathrm{F}$ & White & 20 & 1 & 3-4 days/week, 30-75 min \\
\hline Lynn & $\mathrm{F}$ & White & 21 & 1 & $\begin{array}{l}1 \text { day/week, } 45 \text { min, plus daily } \\
\text { spontaneous explorations/ } \\
\text { discussions }\end{array}$ \\
\hline Margie & $\mathrm{F}$ & White & 25 & 1 & 3 days/week, $15-90 \mathrm{~min}$ \\
\hline April & $\mathrm{F}$ & White & 16 & 2 & $\begin{array}{l}2 \text { days/week, } 45-60 \mathrm{~min} \text {, plus daily } \\
\text { science center }\end{array}$ \\
\hline Abby & $\mathrm{F}$ & White & 6 & 2 & 2 days/week, $45-60 \mathrm{~min}$ \\
\hline Blair & $\mathrm{F}$ & White & 2 & 2 & $\begin{array}{l}3 \text { days/week, } 45-60 \text { min, plus daily } \\
\text { science center }\end{array}$ \\
\hline Bonnie & $\mathrm{F}$ & White & 19 & 3 & 3 days/week, $75 \mathrm{~min}$ \\
\hline Shea & $\mathrm{F}$ & Mixed & 1 & 3 & 3 days/week, $60 \mathrm{~min}$ \\
\hline Donna & $\mathrm{F}$ & White & 25 & 4 & 3 days/week, $60 \mathrm{~min}$ \\
\hline Marie & $\mathrm{F}$ & White & 14 & 5 & 3 days/week, 60-90 min \\
\hline Sally & $\mathrm{F}$ & White & 40 & 5 & 5 days/week, $70 \mathrm{~min}$ \\
\hline Maya & $\mathrm{F}$ & White & 1 & 5 & 5 days/week, $55 \mathrm{~min}$ \\
\hline
\end{tabular}

$60 \mathrm{~min}$, during the spring of 2017. We used a semi-structured interview protocol (Appendix), while also allowing for probing questions. This type of interview allowed us to gain similar information from each STE about their science teaching experiences while also allowing for the individual to focus on ideas that they felt were important and provide context for their perspectives (Patton, 2002). The following winter, we conducted follow-up interviews with Shea and Maya during their first year of teaching and used the same questions from the original protocol that relied on classroom experience. In this way, we wanted to see how their ideas of intended science teaching while candidates met with the realities of being a classroom teacher.

\section{3 | Primary data analysis}

To highlight the voices and experiences of the elementary STEs, we used constant comparative coding (Charmaz, 2014) to find emergent themes in the interview transcripts. We chose five initial interview transcripts to individually code for themes and then met together to compare codes. We agreed upon a shared set of codes and meanings, which we then used with the same set of five interviews to see if we were reliably coding similar instances with the same codes. After meeting a second time to compare coding of the first five interviews, we separately coded the eight remaining interviews with the coding scheme. After coding all interviews from our 13 participants, we grouped coded excerpts by themes to determine which emergent themes were the most prevalent across participants, as well as in the data set (see Tables 2 and 3). 


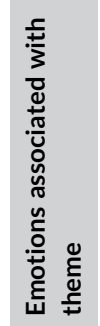

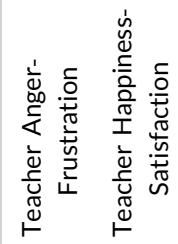
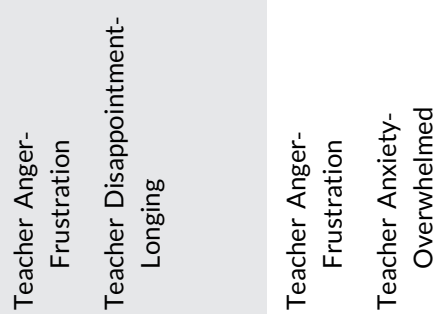

¿․



$\stackrel{+}{\grave{2}}$

ส

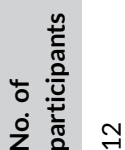

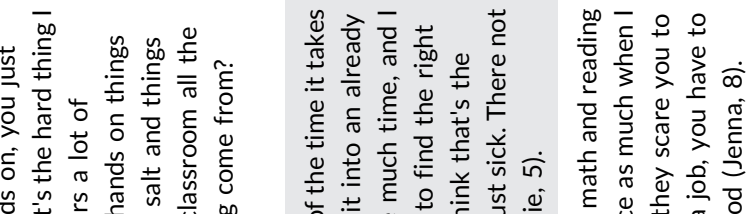

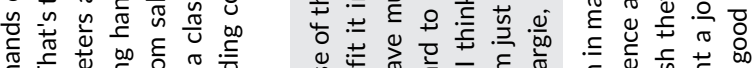

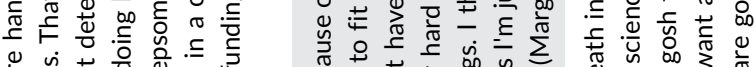
떵

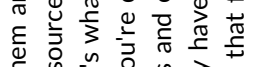

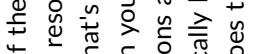

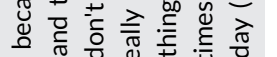
.

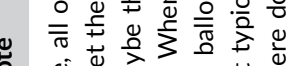

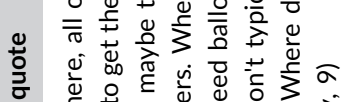

苞离 $\frac{\pi}{0}$ i
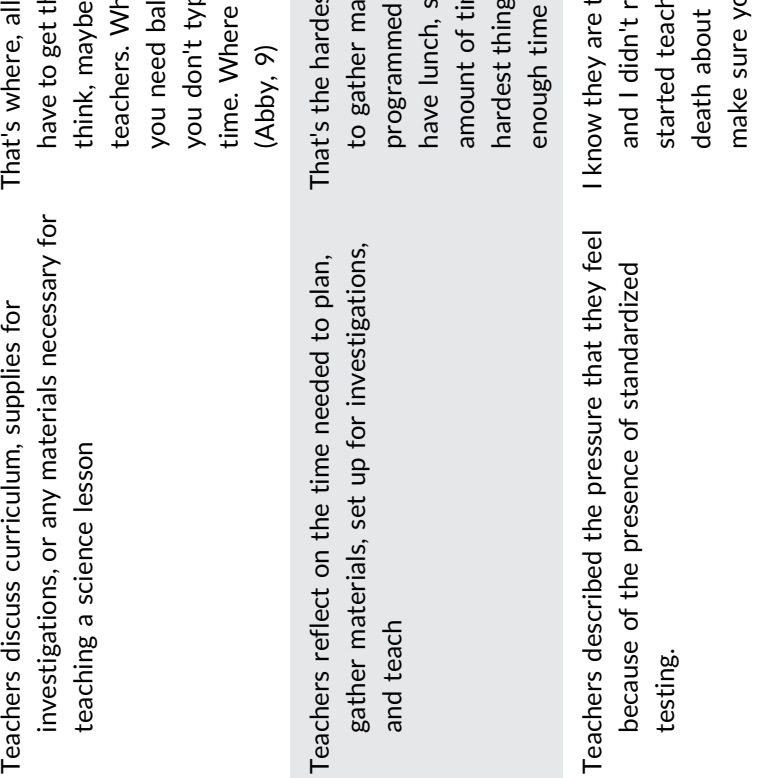

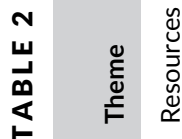

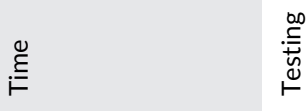




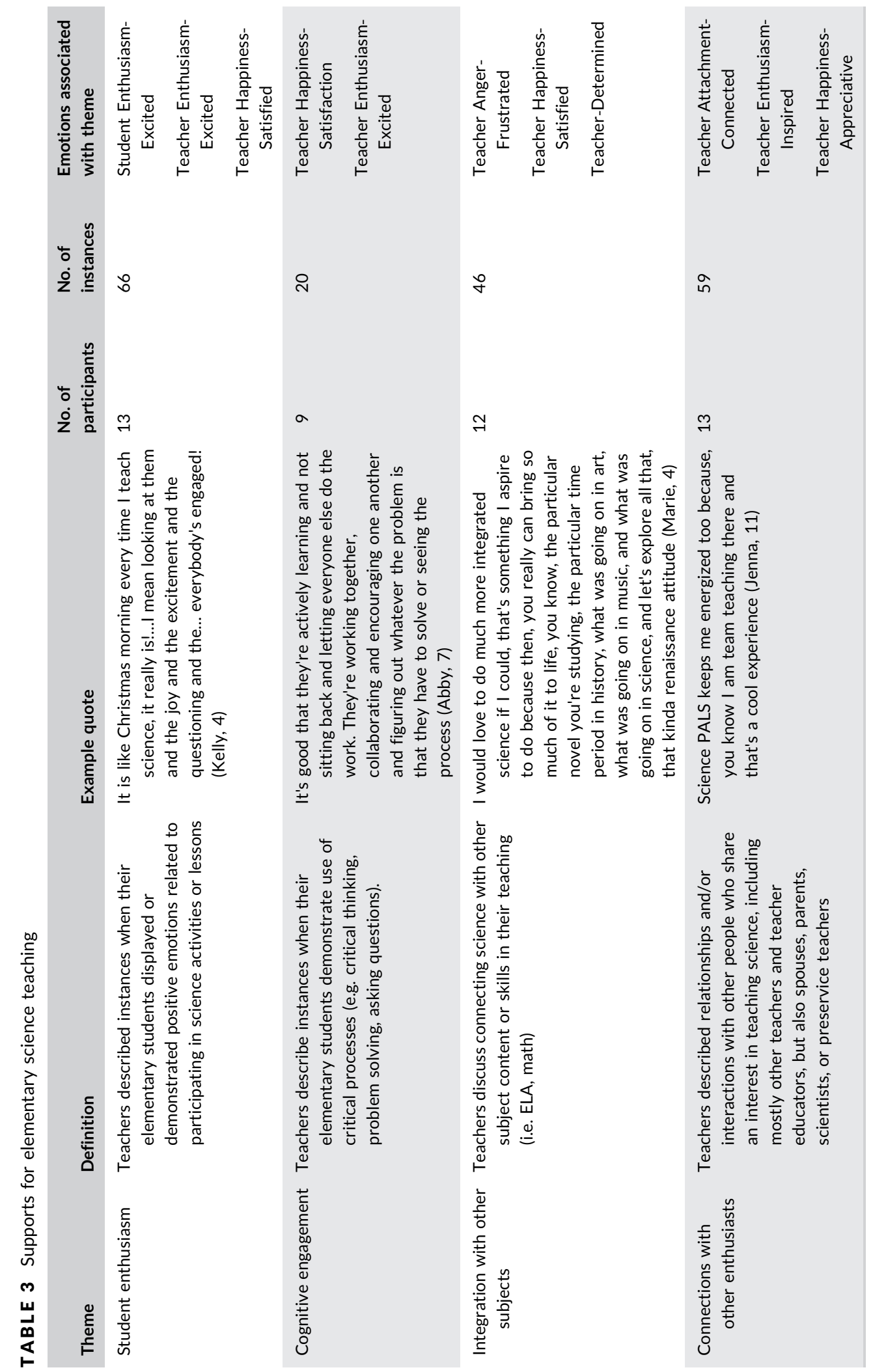




\section{4 | Secondary data analysis}

The central role of emotions related to negotiating their identities as STEs was evident in our participants' descriptions of their experiences. In our original conception of this study, we planned to share participants' experiences as STEs; we did not include emotions as a part of our thinking. However, in our initial coding of the data, the important role that emotions played as the participants described their experiences was evident.

We then re-examined and coded the excerpts from the emergent themes for emotions, for example, instances when teachers were expressing some sentiment about an event or a contextual factor. After we initially used emergent constant comparative coding (Charmaz, 2014) for emotions, we compared our list of emotions with existing literature on teacher emotions (Glomb \& Tews, 2004; Oatley \& Johnson-Laird, 2014; Taxer \& Frenzel, 2015). We then refined our emotions coding scheme using major categories of positive and negative emotions from the literature (e.g., anger, sadness, enthusiasm, happiness, etc.), whereas the sub-categories for each emotion are from our emergent coding (see Table 4). We used this emotions coding framework to recode the emergent theme excerpts.

\section{4 | FINDINGS}

\subsection{Factors that impede science teaching at the elementary level}

Even though there was not a specific question in the interview protocol related to constraints or difficulties related to science teaching, the participants reflected on the topic spontaneously in their conversations about teaching science at the elementary level. The themes identified that were associated with factors that impeded their teaching of science were: resources, time, and testing (see Table 2).

\subsection{Resources for teaching science}

The most frequently cited constraint was access to the resources necessary for teaching science including supplies, tools, and curriculum materials. Margie explained, "I don't have money enough for what I want to do, and so it's hardest to stay up and keep it going" (Margie). Similarly, April noted her own struggles related to materials that she needs to teach inquiry-based science: "I think...the trying to find stuff, I think that's what it is, because the resources are so limited" (April). As she reflected on the beginning of her 40-year career as a teacher, Sally shared the story of going into her first classroom to find that the only materials available were a few books. Her reaction was:

That's not the way to teach science! I'm all about doing stuff with kids most of the time, and so I can remember just little by little just getting some things... If it just meant bringing every jar I had at my house to the classroom, I just started doing all of those things. (Sally)

Most of the participants when discussing a lack of resources for teaching science expressed anger-frustration, however, a couple also noted feeling anxiety-overwhelmed and disappointed-longing.

While the majority of participants expressed negative emotions related to resource availability for science teaching, there were a few who expressed satisfaction about the resources available to them. Lynn's comment was typical of these teachers, she said: 
TABLE 4 Emotions coding framework

\begin{tabular}{|c|c|}
\hline Sub-emotions & Example quote \\
\hline Excited & $\begin{array}{l}\text { So we collected those, and we had tadpoles and all sorts of stuff. So that's really fun, the live part of } \\
\text { it too. I think they're just really excited about it, so that makes me equally as excited. (Blair, 3) }\end{array}$ \\
\hline Amazed & $\begin{array}{l}\text { A lot of my low level learners who struggle with reading, who struggle with writing, often have } \\
\text { amazing science minds and they're able to go through and explain orally how something is } \\
\text { working or why it's working or they can make things happen that a lot of my academic thinkers } \\
\text { cannot. (Bonnie, 8-9) }\end{array}$ \\
\hline
\end{tabular}

Inspired

So, that's inspiring because she [high school teacher] has her eco-club high schoolers come and they help lead the groups, and there's the bug safari, and there's the picking up the stuff in the nets in the water, and then there's learning about composting and recycling, and then there's an art project. So, that's like this total embracing of science for the day, it's wonderful (Marie, 6)

\begin{abstract}
Joyful I do think that a lot of it just comes from my love of it, and that's what makes me want to teach it... You wanna share with people what you love, and I wanna share with them what I love, and I can't share my family with them. I love science, so I'Il share science with them. (April, 9)
\end{abstract}

\title{
Happiness $^{b}$ \\ Sub-emotions Example quote
}

Satisfaction we went down to the County Science Center and it was all about push and pull and my kids were answering questions and I think the lady was pretty impressed with what they remembered... they can talk about what we've learned and they could see it in real life. And that makes me feel like, yeah you learned that, it's good. (Lynn, 4)

Appreciative I don't know a lot about it, except from a first grade perspective, but like [x program] has really helped me gain a lot of knowledge you know like with bigger ideas and concepts. (Jenna, 2)

Attachment

\section{Sub-emotions Example quote}

Connected Having a partner to teach science with. We have to be on for each other, I'm talking about Kelly. We both take responsibility for parts of the lessons. I do a lot of the supplemental things, building the background knowledge, the content part. She does more of getting the materials together. If one person is doing everything, it's overwhelming. (Donna, 6)

\section{Determination}

\section{Example Quote}

I will not have a worksheet or something tied to every bit of [content] that we do, not those last few days, I won't...I want them to have good memories of it and I just want them to love science because that's what makes our world go round. (April, 4-5)

Disappointment

\section{Sub-emotions Example Quote}

Longing I have been around long enough that I've had good staff development in the county. I've had some from [university], who had some of our teachers involved, and then I've had some at the county level, but with such a huge focus on testing, it's been a lot of reading, a lot of math, and science is one of the staff developments that have kind of gone to the wayside. (Bonnie, 6)

\section{Anger}

\section{Sub-emotions Example Quote}

Frustrated I just wish the teachers had freedom to [teach science], and not feel like they're in a chokehold on math and reading. You know, there is a pressure for those subjects of course because those subjects are the basis for the continued learning in science and social studies. (Abby, 11) 
Anxiety ${ }^{f}$

\section{Sub-emotions Example Quote}

Overwhelmed I would love to do much more integrated science if I could, that's something that I would aspire to do because then, you really can bring so much of it to life, the particular novel you're studying, the particular time period in history...but you have be this 'supreme' planner and organizer and so many of us are just trying to find a clean pair of underwear to put on. (Marie, 4)

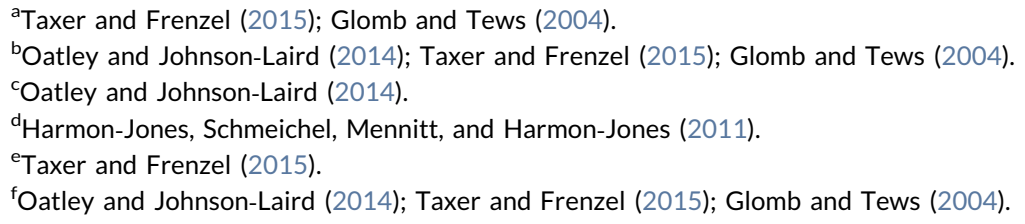

I know I can do that lesson, and I have everything there and ready for me. I have all the different types of rocks and there's sand and silt and rocks all built in and then the kids sift through it. So, I don't have to say, oh gosh, I have to get this stuff together, it's there, it's ready. (Lynn)

A few participants noted both positive and negative emotions related to resource availability, due to having materials for some topics and not others-Lynn was one of these. Even though some participants expressed mixed emotions about this topic, only one participant (Shea) described having adequate resources to teach science using reform-based methods.

\section{3 | Time}

Participants discussed the difficulty they faced in having enough time to plan and set up materials for science lessons in addition to finding the time in a busy day to teach it. April reflected on the comments she received about finding time to teach science when she transitioned from being a middle school teacher back to teaching at the elementary level. She said, "Some don't see it as important as I see it, and those people tell me, "You can't do your science all the time..." that hurt because I think we gotta make time for it" (April). Lynn noted her frustration with trying to fit science into her daily schedule when she was faced with not enough time to teach every subject adequately: "I don't miss reading or math ever, but if we don't get to the science lesson, it will have to be put on the next day...So I would like to maybe not do that." (Lynn). Even though many of the teachers had the flexibility to alter their classroom's schedule and a desire to include science daily, they noted that this was a difficult task.

Others noted how hard it was for them to find time to plan for science lessons and set-up materials. When her schedule changed from what it had been the previous year, Kelly discussed the difficulty in finding time to set up her hands-on science activities, "When it was in the morning before school started, if I had the afternoon to set it up, I could...the time to set it up was probably the biggest hiccup" (Kelly). Marie observed the difficulty that she and her colleagues felt in finding time to prepare for science teaching: "People feel like they just don't have time and they can't fit it in, some of that time I think is spent just trying to dig stuff up and get it together. So, that could be a stumbling block too." (Marie). For participants who discussed the issue of time, they struggled to find time to prepare for the lessons, and to find time in their busy days to implement the lessons.

Participants expressed anger-frustration as they talked about the difficulties related to time to prepare and teach science. Margie stated, "That's the hardest because of the time it takes to gather materials and to fit it into an already programmed day. I don't have much time" (Margie). Sally reflected on her frustration with others who were not always able to find time in the day for science. She commented, "When I go to...grade level meeting[s] over the 
years, and when I hear people say, "I might get, maybe on Friday afternoons before we go outside, I might get thirty minutes in," I'm just like NO!" (Sally).

The STEs also communicated teacher disappointment-longing as they described how time constraints kept them from reaching their goals for science teaching. Abby shared her longing for more innovative science teaching stating, "I want to know what more exciting things and ways there are to teach the objectives to the kids. I think that it just takes time to carve out and do that" (Abby). For our participants, the primary emotions associated with time were negative as they worked to balance all of the demands on their time, including preparing for and enacting science lessons.

\section{4 | Testing}

The pressures connected to testing were felt by more than half of our participants. Participants described feeling pressure to ensure that students were prepared for standardized tests, most frequently in math and English Language Arts. In an excerpt where she discussed the wide-ranging academic levels of her second-grade students, Abby explained:

I think the pressures for math and reading are so intense, I understand why science and social studies are easier to drop and not focus on because you have so many expectations to get our kids, who range from kindergarten to fourth grade level, and math is all over the place too, so it's hard to balance that effectively.

Donna also explained that she felt the testing pressures for reading were especially intense for primary grade teachers. Marie noted that as a fifth-grade teacher, which is a tested subject in her state, she often feels frustrated with her lower grades colleagues when they do not make time to teach science because their students are not tested. She paraphrased what she hears from her colleagues: "Well, it's not tested until fifth grade, so we're not gonna really worry about it until it has to be tested" (Marie). As a veteran teacher, Sally shared her perspective on how the implementation of accountability measures related to testing for math and reading has changed the willingness of teachers to make science teaching a priority:

We've had so much emphasis on math and reading and writing, and I get those are important, but there was a while there when all this testing really started, the high stakes testing, I think that really kinda made a real bump in the road with science education...The stress related to the tests...it just has changed, the attitude has changed...There was a time, people were so afraid of what their test scores were going to be, that that was their focus. "Well I might get in science once a week"

As participants discussed the realities of testing in their particular contexts, the most frequently expressed emotions were teacher anger-frustration and teacher anxiety-overwhelmed. Abby expressed her frustration stating, "I just wish the teachers had the freedom to do it, and not feel like they are in a chokehold on math and reading. You know, there is a pressure for those subjects." No matter which grade level their current teaching assignment was for, the participants noted that testing for math and reading negatively impacted instruction in science in every grade.

\section{5 | Factors that promote science teaching at the elementary level}

While our participants encountered negative factors related to their experiences teaching science, more often they chose to focus our conversation around factors that positively impacted their identity as STEs. The most frequently 
reported supports were: enthusiasm for science displayed by their students, the opportunity for student cognitive engagement when participating in science, possibilities for integrating science with other content areas, and connections with other science enthusiasts (see Table 3).

\subsection{Elementary student enthusiasm}

The most prevalent theme discussed by participants was the importance of their elementary students' enthusiasm for science as a reason that the STEs were excited to plan and teach science lessons. In these excerpts, participants described occurrences where they felt their students enjoyed participating in science lessons. In some cases, participants referred to science activities in a general sense. For example, Sally explained, "I just think when you're showing enthusiasm, and it's so cool when they figure something out or when they want to know more. That's my enthusiasm, it's really tied to the kids." Similarly, Bonnie shared:

I love to do hands-on observations with them and watch their faces explode when they either guess right or guess wrong and then something happens. I love to see that because I know all of a sudden, it explodes a thousand questions in their head and they are just starving for more. I love that!

In other examples, participants discussed specific lessons that they had implemented that they felt generated a positive student reaction. Marie's quotation is typical of this type of example. She stated, "Some of these kids own drones, yet they can still delight in building their cars, and strapping in their passengers, and sending them down ramps, and seeing what happens, and clocking their distances." In the numerous examples reported within this theme, participants described that their elementary students were enthusiastic about science and science teaching, and in some excerpts, they clearly articulated that the pleasure shown by the students influenced their own enthusiasm for science teaching.

Within the data for student enthusiasm, the three most frequently reported emotions were student enthusiasm-excited; teacher enthusiasm-excited; and teacher happiness-satisfied. As the participants discussed students' enthusiasm for science, they emphasized both the students' and their own excitement about science experiences with all participants expressing a positive emotion related to students, and most relaying positive emotions about their own excitement. They repeatedly used words like excited, fun, and joy to describe their own and students' reactions to what happened during science lessons. In some cases, participants indicated that there was a reciprocal relationship between the students' excitement and their own, with each feeding the other. April's excitement is evident as she states, "They want to know why and it pushes them, and they enjoy it...and honestly, them seeing me get excited about it is huge, and maybe that's why some of them are excited about it "cause I get excited!" Maya, a first-year teacher, also noted the connection between her students' emotions and her own related to science learning: "they're always excited about what we're going to do next. If we're going to do an experiment. So the engagement piece is always there, so that's really motivating for me." Nine participants also signified a sense of satisfaction related to these positive science teaching experiences. Participants used words and phrases like "success" and "felt good" to indicate that they were satisfied with some aspect of their science instruction. Another common way that teachers signaled satisfaction was by telling stories about parents or former students who commented on particular science experiences that they remembered.

\section{7 | Student cognitive engagement}

Participants indicated that they felt encouraged to teach science because of the opportunities it provides for students to be cognitively engaged, with teachers specifically focusing on student use of problem-solving and 
critical thinking skills. Bonnie appreciated that science lessons provided the chance for many types of learners to succeed. She stated:

That's another thing that gets me excited because a lot of my low level learners who struggle with reading, who struggle with writing, often have amazing science minds and they're able to go through and explain orally how something is working or why it's working or they can make things happen that a lot of my academic thinkers cannot.

Maya felt successful as a teacher when "the kids are able to ask critical questions." Lynn articulated her enjoyment of engaging in scientific observations and thinking alongside her students:

I like it when children are curious enough to question...So that's why I like teaching science because I like their questions and the ideas that they come up with... So if they flip over a rock and they see something then I want to know what's there, and if I can't tell them, then together we will look it up and we'll ask each other and try to figure it out.

Beyond scientific conceptual understanding, participants consistently valued time when science instruction provided an opening for students to develop their thinking skills.

The two most common emotions that participants associated with the students' cognitive engagement were teacher happiness-satisfaction, and teacher enthusiasm-excited. Teachers shared their satisfaction and excitement related to times that they felt students were cognitively engaged and demonstrated curiosity or wanted to go deeper into a topic. Abby noted her feeling of satisfaction when her students were successful in expressing accurate science content: "I think just seeing the conversations that I have with them and knowing they really do understand that's when I'm like, 'Yes!'” While the pattern for the data related to this theme indicated that teachers used less emotive language about the cognitive engagement of their students as compared to the other prevalent themes, they still demonstrated positive emotions around this topic.

\section{8 | Integrating science content}

A prevalent theme in participant responses related to how they fit science teaching into their day was the possibility for integrating science with other content areas within the elementary curriculum. Jenna stated:

I don't really teach subjects separately if that makes sense. So I look at my big topics and usually those are in science and then... that's where I start. And then I think about what kind of math can I incorporate with that and what kind of literature can I incorporate with that?

Jenna's explanation of integration was similar to that provided by several other participants, including Sally and Bonnie, who saw science as a means for using other math and language arts skills. Shea, a first-year teacher, reflected on why she thought integration was an appropriate approach with her elementary students:

Ideally, I'd like to teach science in a really integrated way where you don't have this break up of subjects because ultimately... whatever profession you do, your day's going to be integrated. You're not breaking your day up into subjects. I think science is one of the best ways to integrate anything.

While there were differences in the level of detail in their descriptions of integration, for the majority of our participants, an integrated approach was a viable option for ensuring that science was included in their busy days. 
Interestingly, the most commonly reported emotion related to integration was a negative one. More than half of the participants reported feelings of frustration around this theme. However, their frustration stemmed from their belief that more colleagues should be teaching using an integrated approach. Bonnie's comment was typical of the emotions expressed by several participants in regards to other teachers:

I think we need to be focusing more on integration, more on how to plan through content because I think it's doable. But I also see teachers who are experienced who do very well who also don't understand or want to do that.

The second most commonly conveyed emotion was happiness-satisfied. Participants expressing this emotion were often reporting examples of times that they felt that they had accomplished the goal of connecting science to other content areas such as when students had successfully engaged in public speaking and written communication about a science experience or when students' curiosity about a science topic compelled them to want to read to learn more about it. Participants expressed determination as they described their goal to continue to integrate multiple content areas in their instruction. April demonstrated her determination as she described how she felt that integration was a way to mitigate issues related to accomplishing all of her goals in a busy school day acknowledging, "I try to integrate it [science] as much as I possibly can because really, that's how I'm going to get it done." In responses where they communicated determination, participants expressed their own willingness to put forth the effort and time to plan lessons that incorporated science with other content areas.

\subsection{Connections with other enthusiasts}

A frequently mentioned support was the personal connections that participants had with others whom they viewed as STEs. The most frequently mentioned connections occurred with other teachers and teacher educators, however, participants also mentioned parents, spouses, and teacher education students as important resources. Blair described an example of a connection with a science educator (one of the authors) who was formerly her science methods instructor. She recounted a time when the science educator came to work with her and her students:

I liked when we did the ladybug thing last year and partnering with schools. I'm always willing to do stuff, I assume others are too. Anytime someone is like, "do you want me to come to your class to talk about this or work with you on this?" I'm like, "let's do it!" I think a lot of people are open to stuff like that.

Participants often mentioned connections to other teachers at their school and beyond who helped keep them motivated for science teaching. Abby described relationships that she had developed with other teachers at her school, she said, "We'll swap units sometimes, I'll just give a whole manila folder of things we did and the pacing." For seven of our participants, a local teacher-led group provided important connections with other teachers. The school system where most participants work previously had a grant-funded program led by one of our participants, Kelly. The program focuses on partnering elementary and middle school teachers and their students to participate in inquiry-based science activities, the result of which brings together teachers on a regular basis to discuss science teaching ideas. Donna's discussion of her partnership with Kelly is indicative of the connections fostered by this program. She explained:

Having a partner to teach science with-we have to be on for each other. I'm talking about Kelly. We both take responsibility for parts of the lessons. I do a lot of the supplemental things, building the background knowledge, the content part. She does more of getting the materials together. If one person is doing everything, it is overwhelming. 
While the types of interactions that they described may have been different, the majority of our participants discussed the importance of other STEs in helping them stay prepared and motivated for science teaching.

The three most frequently coded emotions related to connections with other enthusiasts were: teacher attachment-connected; teacher enthusiasm-inspired; and teacher happiness-appreciative. Whether through the local teacher group, science educators, or other colleagues, our participants valued the connection that they felt with others. As a first-year teacher, Maya sought out others who she could share ideas with. In referring to another teacher, she said, "he and I have talked, ongoing discussions about what he did when he taught science and what I'm doing and what works. So we have had good authentic discussions." In several excerpts, participants relayed that they felt inspired in some way by these interactions with colleagues. Marie used the word inspired to describe a connection with a high school teacher, while Sally felt that her regular connections with preservice teachers "lifts you back up." In their conversations, the participants expressed feelings of appreciation that they had these connections with others who liked to teach science. As she described a long term partnership with the authors in which two science educators collaborated with teachers at her school, Abby shared that she felt appreciative of the opportunity to work together:

Having it [a 5E lesson] modeled was really great, there were a lot of things that helped me. Knowing what questions to ask, thought-provoking questions versus 'what is this...just being able to do that with teachers in our building, I know we've all appreciated it.

Whether the interactions were with colleagues or other science enthusiasts, the participants overwhelmingly expressed positive emotions. Within this theme, the only negative emotions were related to a desire for more interactions with others.

\section{5 | DISCUSSION}

The purpose of our study was to examine the influential factors that impacted elementary teachers' identities as STEs and the role that emotions played in the development of such an identity. The authoring of identity is a dialectical process between one's self and others that is impacted by the figured world in which interactions occur (Holland et al., 1998). Research literature supports the perspective of our participants who described a figured world in which the availability of science teaching resources (Appleton \& Kindt, 2002; Milner et al., 2012), time to gather, plan, and implement science teaching (Davis et al., 2006; Milner et al., 2012), and accountability measures related to testing in math and reading (Carlone et al., 2010; Upadhyay, 2009) negatively impacted their ability to teach science in the ways they desired. Given that all of the teachers other than one worked in rural Title 1 schools, the identification of constraints related to resources is not atypical. Our participants conveyed negative emotions when discussing these constraints on their flexibility to include science consistently in their teaching schedules. Their observations of their teaching context describe a figured world that is structured to prioritize the teaching of other subjects due to institutional policies that teachers do not have the power to directly influence. For example, our participants are not the ones in charge of making accountability policies or budget priorities that would pay for teaching resources or time to devote to planning for science instruction. This figured world positions the participants in a way that constrains their ability to author a positive science teaching identity. The negative emotions of anger-frustration, anxiety-overwhelmed, and disappointed-longing are not surprising given the lack of control these teachers describe in relation to the structural barriers around a subject they have a passion for teaching. While our study focused on 13 participants, the figured world they describe and the constraints they perceive that they face help to explain the lack of change in the amount of time science is being taught at the elementary level nationally (Banilower et al., 2018; Weiss, 1978). 
Factors that supported their development of an identity as an STE included their students' enthusiasm for doing science, elementary students' cognitive engagement, integrating science content, and their connections with other STEs. Student enthusiasm was the most often mentioned support for the participants, who overwhelmingly described the role that students' pleasure in studying science played for them in keeping them motivated to teach more science. As described by Jaber and Hammer (2016b), the pleasure of participating in science investigations is a component of epistemic affect. Experiencing joy in the doing of science motivates interest in the subject area (Jaber \& Hammer, 2016b). For the STEs in this study, their students' enjoyment in inquiry-based science activities was mentioned as a strong motivator in their continued teaching of science and as a contributor to their positive science teaching identities. This finding is similar to the work of other researchers who have established that positive interactions with students can contribute to the development of stronger science teaching identities amongst both preservice (Carrier et al., 2017) and in-service teachers (Carlone et al., 2010; Zembylas, 2004).

Our participants were similar to those that Hargreaves (1998) described in that they had a desire to plan and teach activities for which the students would positively respond to and engage in. Findings related to student enthusiasm and engagement and how that influenced our participants' desire to teach science mirrors results found by Frenzel et al. (2009) in their work with middle school mathematics teachers and students. Frenzel et al. (2009) explain a positive feedback loop link between teacher and student enthusiasm, that teachers' show more enthusiasm for teaching a subject when students express enjoyment in learning. Additionally, a teachers' enthusiasm positively impacts student motivation to learn that subject (Frenzel et al., 2009). The positive emotions for our teachers as a result of the students expressing excitement and enjoyment for learning science leads teachers to want to spend more time teaching it.

Our participants reported many positive emotions related to both students' enthusiasm during science lessons, as well as their level of cognitive engagement during those lessons. The STEs in this study expressed positive feelings when their students' generated questions or demonstrated an interest in learning and investigating more deeply about particular science topics. Evidence of elementary students' affective signals of cognition related to questioning is another component of epistemic affect (Jaber \& Hammer, 2016b) described by our participants as a support for their positive science teaching identities. The positive emotions around their science teaching experiences are reinforcing their desire to teach science more often than they feel they are able to because of the previously described constraints in the figured world of the elementary classroom. Holland et al. (1998) explain that our experiences in figured worlds position us to consistently respond to events. Every action we take is a response to how we are positioned, whether that response is to acquiesce and reproduce the status quo, or to find ways to improvise and push back on a given set of constraints. Agency is a person's ability to find ways to act differently in a given situation. For our participants, the positive emotions related to their students' enthusiasm and cognitive engagement position the teachers to feel the tension between the constraints on their ability to teach science and their desire to teach science. Their emotions around science teaching play a central role in their identity development and how they make sense of experiences, as discussed by Rivera Maulucci (2013). As Rivera Maulucci (2012) states, "our emotions may be seen as one of the central mediators of our identities," (p. 125), and emotions are evidence of how teachers make sense of who they are in relation to what they value and the context in which they work (Rivera Maulucci, 2013). Researchers have noted that teaching is a form of emotional labor, an inherently emotional practice (Hargreaves, 1998; Zembylas, 2004). For our participants, their positive emotions contribute to their willingness to author a different identity related to their science teaching-that of a STE.

Integrating science with other content and connecting with other STEs were tools our participants used to improvise within the figured world of their elementary schools. Constraints on their time and resources, as well as testing pressure for other subjects created a tension for teachers against their desire for teaching science more consistently. Our participants recognize the potential of integrating science and other subject areas, and mention the time and effort it takes to plan these integration connections meaningfully. Many studies have described the positive outcomes for achievement in both disciplines when science is integrated with language arts (Bradbury, 2014; Romance \& Vitale, 2001), as well as the impact on student attitude towards science (Patrick et al., 2009; 
Shymansky et al., 2004). Interestingly, although participants talked about integration as a tool to work within the constraints of their figured world, they routinely expressed the negative emotion of frustration as they felt that their colleagues should be engaging in this practice more frequently. When they described experiences of integration in their own classrooms, they expressed positive emotions such as satisfaction at the results and determination to put it into practice more often.

These findings support the notion that their emotional responses to using integration as a tool of improvisation reinforce their continued use of the tool as a way to author a STE identity. As our participants enacted a STE identity, they needed tools to help them work within the constraints. Integration of science with other subjects served as a tool because it allowed them to mediate the constraints of time and testing pressures. Participants described that they could fit science content into time allotted for other subjects if they integrated skill objectives from math or language arts.

In addition to describing how they try to fit science teaching into their schedule more frequently, the teachers also shared how important their connections with other STEs were for their motivation to teach science regularly. To negotiate the constraint of resources, our participants described the importance of time spent with other STES to share ideas, which helped them with planning. The emotional responses they expressed related to these connections were positive including attachment-connected, enthusiasm-inspired, and happiness-appreciative. As they reflected on how they stayed motivated to teach science, our participants described the importance of other science enthusiasts. Collaboration with other professionals, whether they were teachers, science educators, or preservice teachers, enabled the participants to feel supported in their positive views of science and helped them to push each other to grow professionally (Luft \& Hewson, 2014). Other researchers have noted the importance of communities of like-minded teachers with personal bonds working together to share ideas and new practices (Appleton \& Kindt, 2002; Hargreaves, 2001; Jones \& Leagon, 2014). In a study by Feille et al. (2018), teachers in a long term professional development recounted that they valued the sense of community developed with other teachers more than any other aspect. Hargreaves (1998) reported the positive emotional reaction and sense of excitement that teachers had as they planned with other teachers. The participants in our study emphasized the significant role that both their students and colleagues played in strengthening their work as they author positive science teaching identities.

\section{6 | IMPLICATIONS}

While the prevailing narrative focuses on a deficit view of elementary teachers with respect to science teaching, there are signs of hope in the reports of elementary teachers who are able to overcome both structural and individual constraints to implement science as a meaningful aspect of their curriculum. The participants in our study have authored a positive science teaching identity in which their view of themselves as an elementary STE plays a central role in their teaching practice. These teachers use supports such as their students' enthusiasm and their connections with other STEs to overcome these barriers and include science consistently in their classroom instruction.

In thinking about the impact of this work for science educators, we are left with three implications for developing and strengthening the science teaching identities of elementary teachers: (a) supports for science teaching experiences which engage and excite elementary students; (b) connections with other STEs; and (c) more research on the role of emotions in developing science teacher identities. We will discuss each of these in the order listed above.

Positive science teaching experiences with elementary students and their accompanying emotions provided an important support for the strengthening of STEs' science teaching identity. Therefore, science educators should consider ways to help facilitate opportunities for elementary teachers to regularly engage in science teaching. In our own work, we have been reflecting on how to mitigate some of the constraints that teachers feel impede their 
regular science teaching (resources, time, and testing pressures). One way is to build on the participants' ideas about the role that integration can play in allowing time to fit science into their teaching schedules and address anxiety related to testing pressures and building math and language arts skills. Another way to help teachers feel prepared to regularly implement science teaching is through providing models of activities that address content standards across disciplines with the use of everyday materials so that resources are not an insurmountable roadblock to their teaching. Finally, science educators should consider how to include planning time in professional development with elementary teachers, as time to plan with others was a significant constraint in teachers' consistent enactment of science teaching.

Given the significant role that connections with other STEs played in supporting the positive science teaching identities of our participants, it is important for professional developers and science educators to consider the inclusion of collegiality and collaboration in the planning and facilitation of their programs with elementary teachers. Our participants found the local coteaching science program, opportunities for working with other enthusiasts, and partnerships with local science educators as supportive of their initiatives to include science as a regular part of their teaching. Researchers have found that relationships between teachers with like-minded interests are important in developing stronger science teaching identities (Carlone et al., 2010; Jones \& Leagon, 2014). Building these relationships may be especially important for novice and preservice teachers as a way to establish the beginning of a positive science teaching identity (Avraamidou \& Zembal-Saul, 2010; Davis et al., 2006). In our own work, we are considering how to leverage our relationships with local STEs to provide internship placements for our elementary preservice teachers so that they can have a positive role model related to science teaching. Our hope is that if preservice teachers begin their careers with an initial network of other science teaching enthusiasts, they may feel capable of working science into their teaching despite the structural constraints of the elementary context. This is an area in which future research could focus to determine how best to develop and support these relationships in internships.

Given the importance associated with positive emotions related to elementary science teaching in providing support for our participants' identities as STEs, we need additional studies exploring the emotions associated with elementary science teaching. This research should include studies of preservice, novice, and experienced inservice elementary teachers. While there is an emerging body of literature related to science teaching and emotions, it has focused on measuring physiological changes related to emotions while teaching (e.g., Tobin et al., 2016). Given the promise of research related to epistemic affect and its role in motivating student interest in learning science (Jaber \& Hammer, 2016a; 2016b), an area of future research is the role that epistemic affect holds for teaching science. Another way to add to our understanding of the impact of teachers' emotions would be to conduct studies of teachers' perceptions of their emotions related to their work and how that influences their decision making and implementation of science teaching. Research in this area of emotions as a factor in the development of science teaching identities should be expanded to include studies with larger sample sizes, as well as including participants at different career stages, of color, and who teach in different contexts. What little research has been conducted on emotions and science teachers has focused on cases of one (Rivera Maulucci, 2013; Zembylas, 2004) and three teachers (Rivera Maulucci, 2012), and our participants themes reflect their own positional identities. An additional area where research is needed is to focus on the role of emotions for teachers in different career stages, including more experienced teachers. For example, two of the previously mentioned studies focus on preservice and novice teachers (Rivera Maulucci, 2012, 2013). This is important work because we need to understand the role of emotions related to science teaching identities at different points in teachers' career trajectories to better support teachers at different points in their careers. In addition, future research involving STEs from underrepresented groups would provide insight into how positive science teaching identities can be nurtured in multiple contexts.

In our introduction, we discussed the prevailing narrative that focuses on negative reports of elementary science teaching, and how that narrative while informative, has not led to substantial changes over time. We found that our participants offered a different perspective, one of the possibilities. While they acknowledged difficulties that they faced in their science teaching, our participants chose to emphasize their determination to regularly 
include science teaching in their work. Though we cannot and should not ignore the reality of the structural barriers, we as science educators can play a role in helping elementary teachers maximize the effect of the positive and supportive factors that impact their identities as STEs.

\section{ACKNOWLEDGMENTS}

The authors would like to thank all of the participants in this study for generously sharing their time and ideas with us.

\section{ORCID}

Leslie U. Bradbury (D) http://orcid.org/0000-0003-2840-7200

\section{REFERENCES}

Appleton, K. (2003). How do beginning primary school teachers cope with science? Toward an understanding of science teaching practice. Research in Science Education, 33, 1-25.

Appleton, K., \& Kindt, I. (2002). Beginning elementary teachers' development as teachers of science. Journal of Science Teacher Education, 13(1), 43-61.

Avraamidou, L. (2014). Studying science teacher identity: Current insights and future research directions. Studies in Science Education, 50(2), 145-179.

Avraamidou, L., \& Zembal-Saul, C. (2010). In search of well-started beginning science teachers: Insights from two first-year elementary teachers. Journal of Research in Science Teaching, 47(6), 661-686.

Banilower, E. R., Smith, P. S., Malzahn, K. A., Plumley, C. L., Gordon, E. M., \& Hayes, M. L. (2018). Report of the 2018 NSSME+, Chapel Hill, NC: Horizon Research, Inc.

Beauchamp, C., \& Thomas, L. (2009). Understanding teacher identity: An overview of issues in the literature and implications for teacher education. Cambridge Journal of Education, 39(2), 175-189.

Beijaard, D., Meijer, P. C., \& Verloop, N. (2004). Reconsidering research on teachers' professional identity. Teaching and Teacher Education, 20, 107-128.

Bradbury, L. U. (2014). Linking science and language arts: A review of the literature which compares integrated versus nonintegrated approaches. Journal of Science Teacher Education, 25(6), 465-488.

Carlone, H. B., Haun-Frank, J., \& Kimmel, S. C. (2010). Tempered radicals: Elementary teachers' narratives of teaching science within and against prevailing meanings of schooling. Cultural Studies of Science Education, 5(4), 941-965.

Carrier, S., Whitehead, A., Walkowiak, T., Luginbuhl, S., \& Thomson, M. (2017). The development of elementary teacher identities as teachers of science. International Journal of Science Education, 39(13), 1733-1754.

Charmaz, K. (2014). Constructing grounded theory (2nd ed.). Thousand Oaks: Sage.

Coldron, J., \& Smith, R. (1999). Active location in teachers' construction of their professional identities. Journal Of Curriculum Studies, 31(6), 711-726.

Creswell, J. (2007). Qualitative inquiry and research design: Choosing among five approaches (2nd ed.). Thousand Oaks: Sage.

Danielsson, A., \& Warwick, P. (2014). 'All we did was things like forces and motion...': Multiple discourses in the development of primary science teachers. International Journal of Science Education, 36(1), 103-128.

Davis, E. A., Petish, D., \& Smithey, J. (2006). Challenges new science teachers face. Review of Educational Research, 76(4), 607-651.

Davis, E. A., \& Smithey, J. (2009). Beginning teachers moving toward effective elementary science teaching. Science Education, 93(4), 745-770.

Feille, K., Nettles, J. R., \& Weinburgh, M. H. (2018). Silhouettes of development: A tool for understanding the needs and growth of science teachers. Journal of Science Teacher Education, 29(1), 30-45.

Frenzel, A. (2014). Teacher emotions. In R. Pekrun \& L. Linnenbrink-Garcia (Eds.), Emotions in Education (pp. 494-519). New York, NY: Springer.

Frenzel, A. C., Goetze, T., Lüdtke, O., Pekrun, R., \& Sutton, R. E. (2009). Emotional transmission in the classroom: Exploring the relationship between teacher and student enjoyment. Journal of Educational Psychology, 101(3), 705-716.

Gee, J. (2000). Identity as an analytic lens for research in education. Review of Research in Education, 25, 99-125.

Geijsel, F., \& Meijers, F. (2005). Identity learning: The core process of educational change. Educational Studies, 31(4), 419-430.

Girod, M., \& Twyman, T. (2009). Comparing the added value of blended science and literacy curricula to inquiry-based science curricula in two $2^{\text {nd }}$ grade classrooms. Journal of Elementary Science Education, 21(3), 13-32.

Glomb, T. M., \& Tews, M. J. (2004). Emotional labor: A conceptualization and scale development. Journal of Vocational Behavior, 64(1), 1-23. 
Goodrum, D., Cousins, J., \& Kinnear, A. (1992). The reluctant primary school teacher. Research in Science Education, 22(1), 163-169.

Hagenauer, G., Hascher, T., \& Volet, S. E. (2015). Teacher emotions in the classroom: Associations with students' engagement, classroom discipline and the interpersonal teacher-student relationship. European Journal of Psychology of Education, 30(4), 385-403.

Hargreaves, A. (1998). The emotional practice of teaching. Teaching and Teacher Education, 14(8), 835-854.

Hargreaves, A. (2001). Chapter 4: The emotional geographies of teachers' relations with colleagues. International Journal of Educational Research, 35, 503-527.

Harmon-Jones, C., Schmeichel, B. J., Mennitt, E., \& Harmon-Jones, E. (2011). The expression of determination: Similarities between anger and approach-related positive affect. Journal of Personality and Social Psychology, 100(1), $172-181$.

Helms, J. V. (1998). Science-and me: Subject matter and identity in secondary school science teachers. Journal of Research in Science Teaching, 35(7), 811-834.

Holland, D., Lachiotte, W., Skinner, D., \& Cain, C. (1998). Identity and agency in cultural worlds. Cambridge, MA: Harvard University Press.

Jaber, L. Z., \& Hammer, D. (2016a). Engaging in science: A feeling for the discipline. Journal of the Learning Sciences, 25(2), 156-202.

Jaber, L. Z., \& Hammer, D. (2016b). Learning to feel like a scientist. Science Education, 100, 189-220.

Jones, M. G., \& Leagon, M. (2014). Science teacher attitudes and beliefs: Reforming practice. In N. G. Lederman \& S. K. Abell (Eds.), Handbook of research on science education (Vol. 2, pp. 830-847). NY: Routledge.

Kelchtermans, G. (2005). Teachers' emotions in educational reforms: Self-understanding, vulnerable commitment, and micropolitical literacy. Teaching and Teacher Education, 21, 995-1006.

Kunter, M., Frenzel, A., Nagy, G., Baumert, J., \& Pekrun, R. (2011). Teacher enthusiasm: Dimensionality and context specificity. Contemporary Educational Psychology, 36, 289-301.

Luehmann, A. L. (2007). Identity development as a lens to science teacher preparation. Science Education, 91(5), 822-839.

Luft, J. A., \& Hewson, P. W. (2014). Research on teacher professional development programs in science. In N. Lederman \& S. K. Abell (Eds.), Handbook of Research in Science Education (Vol. 2, pp. 889-909). New York: Routledge.

Milner, A., Sondergeld, T., Demir, A., Johnson, C., \& Czerniak, C. (2012). Elementary teachers' beliefs about teaching science and classroom practice: An examination of pre/post NCLB testing in science. Journal of Science Teacher Education, 23(2), 111-132.

Murphy, C., Neil, P., \& Beggs, J. (2007). Primary science teacher confidence revisited: Ten years on. Educational Research, 49(4), 415-430.

Nias, J. (1996). Thinking about feeling: The emotions in teaching. Cambridge Journal of Education, 26(3), $293-306$.

Oatley, K., \& Johnson-Laird, P. N. (2014). Cognitive approaches to emotions. Trends in Cognitive Sciences, 18(3), 134-140.

Patrick, H., Mantzicopoulos, P., \& Samarapungavan, A. (2009). Motivation for learning science in Kindergarten: Is there a gender gap and does integrated inquiry and literacy instruction make a difference. Journal of Research in Science Teaching, 46(2), 166-191.

Patton, M. Q. (2002). Qualitative research and evaluation methods (3rd ed.). Thousand Oaks, CA: Sage.

Pedretti, E., Bencze, L., Hewitt, J., Romkey, L., \& Jivraj, A. (2008). Promoting issues-based STSE perspectives in science teacher education: Problems of identity and ideology. Science \& Education, 17(8/9), 941-960.

Petersen, M. R., \& Dohn, N. B. (2017). Interest and emotions in science education. In A. Bellocchi (Ed.), Exploring emotions, aesthetics, and wellbeing in science education research (pp. 187-202). Switzerland: Springer.

Rivera Maulucci, M. (2012). Exploring linkages between identity and emotions in teaching for social justice in science teacher education. In M. Varelas (Ed.), Identity construction and science education research: Learning, teaching, and being in multiple contexts (pp. 123-139). Rotterdam: Sense Publishers.

Rivera Maulucci, M. S. (2013). Emotions and positional identity in becoming a social justice science teacher: Nicole's story. Journal of Research in Science Teaching, 50(4), 453-478.

Romance, N. R., \& Vitale, M. R. (2001). Implementing an in-depth expanded science model in elementary schools: Multi-year findings, research issues, and policy implications. International Journal of Science Education, 23(4), 373-404.

Romance, N. R., \& Vitale, M. R. (2012). Interdisciplinary perspectives linking science and literacy in grades k-5: Implications for policy and practice. In B. J. Fraser \& C. J. McRobbie (Eds.), Second international handbook of science education (Vol. 2, pp. 1351-1373). Dordrecht, Germany: Springer Publishers.

Roth, K. J. (2014). Elementary science teaching. In N. G. Lederman \& S. K. Abell (Eds.), Handbook of research on science education (Vol. 2, pp. 361-394). New York, NY: Routledge.

Schutz, P. A., Cross, D. I., Hong, J. Y., \& Osbon, J. N. (2007). Teacher identities, beliefs, and goals related to emotions in the classroom. In P. A. Schutz \& R. Pekrun (Eds.), Emotion in Education (pp. 223-241). Burlington, MA: Elsevier.

Shymansky, J. A., Yore, L. D., \& Anderson, J. O. (2004). Impact of a school district's science reform effort on the achievement and attitudes of third- and fourth-grade students. Journal of Research in Science Teaching, 42(8), 771-790. 
Snyder, T. D., de Brey, C., \& Dillow, S. A. (2018). Digest of Education Statistics 2016 (NCES 2017-094). National Center for Education Statistics, Institute of Education Sciences, U.S. Department of Education, Washington, D.C.

Taxer, J. L., \& Frenzel, A. C. (2015). Facets of teachers' emotional lives: A quantitative investigation of teachers' genuine, faked, and hidden emotions. Teaching and Teacher Education, 49, 78-88.

Tobin, K., King, D., Henderson, S., Bellocchi, A., \& Ritchie, S. M. (2016). Expression of emotions and physiological changes during teaching. Cultural Studies of Science Education, 11(3), 669-692.

Upadhyay, B. (2009). Negotiating identity and science teaching in a high-stakes testing environment: An elementary teacher's perceptions. Cultural Studies of Science Education, 4(3), 569-586.

Varelas, M., Pieper, L., Arsenault, A., Pappas, C. C., \& Keblawe-Shamah (2014). How science texts and hands-on explorations facilitate meaning making: Learning from Latina/o third graders. Journal of Research in Science Teaching, 51(10), 1246-1274.

Weiss, I. R. (1978). Report of the 1977 national survey of science, mathematics, and social studies education. Research Triangle Park, NC: Center for Research and Evaluation, Research Triangle Institute.

Weiss, I. R., Pasley, J. D., Smith, P. S., Banilower, E. R., \& Heck, D. J. (2003). A study of k-12 mathematics and science education in the United States. Chapel Hill, NC: Horizon Research, Inc.

Zembylas, M. (2004). Emotion metaphors and emotional labor in science teaching. Science Education, 55, $301-324$.

How to cite this article: Bradbury LU, Wilson RE. Questioning the prevailing narrative about elementary science teachers: An analysis of the experiences of science teacher enthusiasts. Science Education. 2020;104: 421-445. https://doi.org/10.1002/sce.21574

\section{APPENDIX: INTERVIEW PROTOCOL}

How many years have you been teaching?

What grade levels have you taught?

How many days a week do you teach science?

How long is your typical science lesson?

Tell me about how you came to be an elementary teacher.

Do you see yourself as a science enthusiast?

- Why or why not? What does that mean to you?

Do you see your own feelings about science teaching as similar or different from most of your colleagues?

- Why do you think that is?

Tell me about how you came to like teaching science.

What do you enjoy about teaching science?

- Why do you think it's important to teach science in a really busy school day?

Tell us about some of your favorite science teaching experiences.

When do you feel successful as a science teacher?

- How do you know when a science learning experience is a good one?

How do you stay energized to plan and teach science?

What do you think science educators can do to support and build enthusiasm for teaching science amongst elementary teachers?

- Inservice vs. preservice? 